\title{
1 Saliva swabs are the preferred sample for Omicron
}

\section{2 detection}

4 Gert Marais ${ }^{1}$, Nei-yuan Hsiao², Arash Iranzadeh², Deelan Doolabh², Annabel Enoch ${ }^{3}$

5 Chun-yat Chu ${ }^{1}$, Carolyn Williamson ${ }^{2}$, Adrian Brink ${ }^{1}$, Diana Hardie ${ }^{2, *}$

6

7 Department of Medical Microbiology, University of Cape Town, Cape Town, South

8 Africa

9 2Department of Medical Virology, University of Cape Town, Cape Town, South Africa

$10{ }^{3}$ Green Point Diagnostic Virology Laboratory, National Health Laboratory Service,

11 Cape Town, South Africa

12

$13{ }^{*}$ Corresponding author

14 Email: diana.hardie@uct.ac.za

15 
medRxiv preprint doi: https://doi.org/10.1101/2021.12.22.21268246; this version posted December 24, 2021. The copyright holder for this preprint (which was not certified by peer review) is the author/funder, who has granted medRxiv a license to display the preprint in It is made available under a CC-BY 4.0 International license.

\section{Abstract}

19 The Omicron variant is characterised by more than 50 distinct mutations, the majority

20 of which are located in the spike protein. The implications of these mutations for

21 disease transmission, tissue tropism and diagnostic testing are still to be determined.

22 We evaluated the relative performance of saliva and mid-turbinate swabs as RT-

23 PCR samples for the Delta and Omicron variants. The positive percent agreement 24 (PPA) of saliva swabs and mid-turbinate swabs to a composite standard was $71 \%$ 25 (95\% Cl: 53-84\%) and 100\% (95\% Cl: 89-100\%), respectively, for the Delta variant.

26 However, for the Omicron variant saliva and mid-turbinate swabs had a 100\% (95\%

27 Cl: $90-100 \%)$ and $86 \%$ (95\% Cl: $71-94 \%)$ PPA, respectively. This finding supports

28 ex-vivo data of altered tissue tropism from other labs for the Omicron variant.

29 Reassessment of the diagnostic testing standard-of-care may be required as the

30 Omicron variant become the dominant variant worldwide. 
medRxiv preprint doi: https://doi.org/10.1101/2021.12.22.21268246; this version posted December 24,2021 . The copyright holder for this preprint (which was not certified by peer review) is the author/funder, who has granted medRxiv a license to display the preprint in

\section{Introduction}

SARS-CoV-2 variants are characterised by distinct mutations which impact on disease transmissibility, immune escape, diagnostics and possibly tissue tropism.

Omicron, in particular, has an extraordinary number of mutations, with at least 50 mutations across the genome, 30 of which are located in the spike protein and 15 in the receptor binding domain. ${ }^{1}$ While functional change in terms of receptor binding is currently to be elucidated, the pattern of viral shedding and resulting impact on diagnostic sampling methods is currently unknown.

\section{Methods}

As part of an on-going study ${ }^{2}$ to evaluate the diagnostic performance of different sample types, we recruited 382 acutely symptomatic, non-hospitalised patients who presented for SARS-CoV-2 testing between August and December 2021 at the Groote Schuur Hospital COVID testing centre in Cape Town. Paired mid-turbinate (MT) and saliva (SA) swabs were collected and tested by RT-PCR (Supplementary methods).

50 Samples were classified as Omicron or Delta based on whole genome sequencing data, diagnostic PCR target failures and sampling date (Supplementary methods). ${ }^{1,3,4}$ A composite standard for SARS-CoV-2 infection was used for comparison of sample types, with infection considered present if SARS-CoV-2 RNA was detected on either the MT or matched SA swab. 
medRxiv preprint doi: https://doi.org/10.1101/2021.12.22.21268246; this version posted December 24,2021 . The copyright holder for this preprint (which was not certified by peer review) is the author/funder, who has granted medRxiv a license to display the preprint in

\section{Results}

58 The positive percent agreement (PPA) of SA swabs and MT swabs to this standard was $71 \%$ (95\% Cl: $53-84 \%)$ and $100 \%$ (95\% Cl: $89-100 \%)$, respectively, for the

60 Delta variant. This was similar to our previous findings for the Beta variant. ${ }^{2}$

61 However, for the Omicron variant SA and MT swabs had a 100\% (95\% Cl: 90-100\%) and $86 \%$ (95\% Cl: 71-94\%) PPA, respectively (Supplementary Figure 1). The mean RT-PCR cycle threshold differences between MT and SA, using the nucleocapsid gene target as a reference, were $5.2(\mathrm{SD} \pm 5.1, \mathrm{P}<0.0001)$ and $1.5(\mathrm{SD} \pm 5.9$, $P=0.18)$ for Delta and Omicron respectively. The median time from symptom onset to positive test for Delta and Omicron assigned cases was 3 days (range: $1-10$ ) and 2 days (range: $0-7$ ).

\section{Conclusion}

These findings suggest that the pattern of viral shedding during the course of infection is altered for Omicron with higher viral shedding in saliva relative to nasal samples resulting in improved diagnostic performance of saliva swabs. This supports the ex-vivo finding of improved viral replication in upper respiratory tract tissue and possibly altered tissue tropism. ${ }^{5}$ This is an important finding as the current standard of care for diagnosis using swabs of the nasal or nasopharyngeal mucosa may be suboptimal for the Omicron variant. 
medRxiv preprint doi: https://doi.org/10.1101/2021.12.22.21268246; this version posted December 24 , 2021. The copyright holder for this preprint (which was not certified by peer review) is the author/funder, who has granted medRxiv a license to display the preprint in It is made available under a CC-BY 4.0 International license.

\section{References}

81

82 1. Viana R, Moyo S, Amoako DG, et al. Rapid epidemic expansion of the SARS-

83 CoV-2 Omicron variant in southern Africa. medRxiv 2021:2021.12.19.21268028.

84 2. Chu CY, Marais G, Opperman C, et al. Performance of saliva and mid-

85 turbinate swabs for detection of the beta variant in South Africa. The Lancet

86 Infectious Diseases 2021.

87 3. Valley-Omar Z, Marais G, Iranzadeh A, et al. Reduced amplification efficiency

88 of the RNA-dependent-RNA-polymerase (RdRp) target enables tracking of the Delta

89 SARS-CoV-2 variant using routine diagnostic tests. medRxiv

$90 \quad 2021: 2021.10 .01 .21264408$.

91 4. Scott L, Hsiao N-y, Moyo S, et al. Track Omicron's spread with molecular

92 data. Science Commentary 2021:eabn4543.

93 5. HKUMed finds Omicron SARS-CoV-2 can infect faster and better than Delta

94 in human bronchus but with less severe infection in lung. 2021. (Accessed 16

95 December 2021, at https://www.med.hku.hk/en/news/press/20211215-omicron-sars-

96 cov-2-

97 infection?utm medium=social\&utm source=twitter\&utm campaign=press release.) 
medRxiv preprint doi: https://doi.org/10.1101/2021.12.22.21268246; this version posted December 24,2021 . The copyright holder for this preprint (which was not certified by peer review) is the author/funder, who has granted medRxiv a license to display the preprint in It is made available under a CC-BY 4.0 International license.

\section{Acknowledgements}

101

102 This research was funded in whole, or in part, by Wellcome [203135/Z16/Z]. For the

103 purpose of Open Access, the author has applied a CC BY public copyright licence to

104 any Author Accepted Manuscript version arising from this submission.

105

106 Testing was conducted at the Groote Schuur Hospital and Green Point National

107 Health Laboratory Service diagnostic virology laboratories.

108

109 Ethics statement

110

111 This research has been approved by the University of Cape Town Human Research

112 Ethics Committee (Ref: 420/2020).

113

114 Conflict of interests

115

116 The authors declare no conflict of interest 


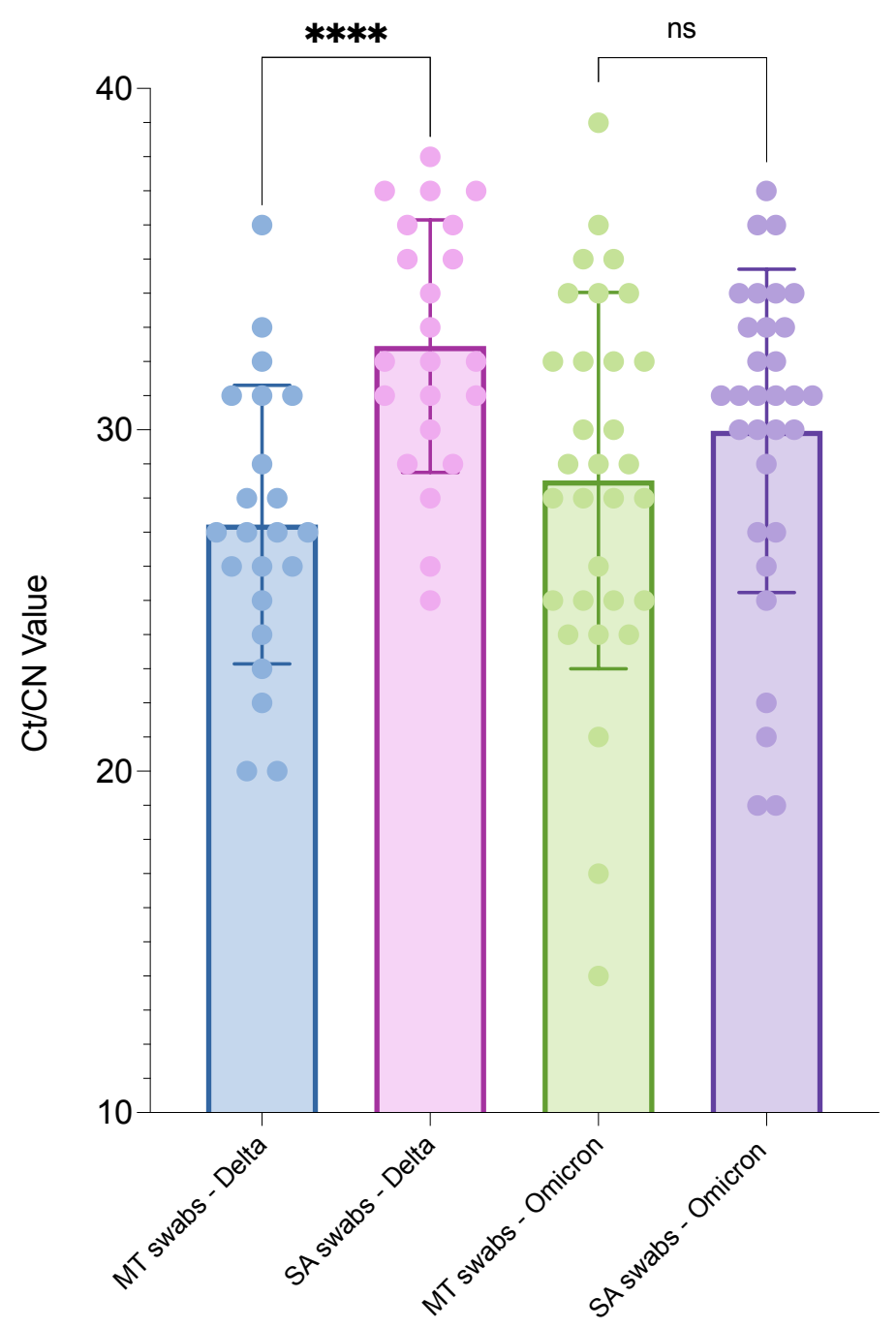

120 Figure 1. The cycle threshold (Ct) or cycle number $(\mathrm{CN})$ values for paired mid-

121 turbinate (MT) and saliva (SA) swabs are shown for Delta and Omicron variant

122 positive samples. Paired samples were tested on the same diagnostic platform on

123 the same day and samples where only the MT or SA swab was positive were

124 excluded from the analysis. The nucleocapsid $(\mathrm{N})$ gene $\mathrm{Ct}$ value was used for

125 analysis if the sample was tested with the Allplex ${ }^{\text {TM }}$ 2019-nCoV assay (Seegene,

126 South Korea). This was because the Delta and Omicron variants are not associated

127 with $\mathrm{N}$ gene target failure and other assays used also target the $\mathrm{N}$ gene. Statistical 
medRxiv preprint doi: https://doi.org/10.1101/2021.12.22.21268246; this version posted December 24, 2021. The copyright holder for this preprint (which was not certified by peer review) is the author/funder, who has granted medRxiv a license to display the preprint in It is made available under a CC-BY 4.0 International license.

128 analysis consisted of paired t-tests performed using GraphPad Prism version 9.3.0

129 for macOS, GraphPad Software, San Diego, California USA, www.graphpad.com.

130 The bar represents the mean Ct value with error bars showing 1 standard deviation.

131 ns: not significant. ${ }^{* * *}$ : $\mathrm{P}$ value $<0.0001$

132 
medRxiv preprint doi: https://doi.org/10.1101/2021.12.22.21268246; this version posted December $24,2021$. The copyright holder for this preprint (which was not certified by peer review) is the author/funder, who has granted medRxiv a license to display the preprint in It is made available under a CC-BY 4.0 International license.

\section{Supplementary methods}

135 Swab collection

136

137 Swabs were self-collected by the study participants under supervision of a

138 healthcare worker.

139

140 Participants should not have had any food, drink, tobacco or gum in the 30 minutes

141 preceding saliva swab collection. Participants were initially instructed to cough 3-5

142 times, covering their mouths with the inner elbow. They were then asked to swab on

143 the inside of both cheeks, above and below the tongue, on the gums and hard

144 palate. A minimum swabbing duration of 30 seconds was required. The swab was

145 transported in a sealed container to the laboratory without any transport media.

147 Mid-turbinate swabs were collected by a healthcare worker. The swab was inserted

$148 \quad 2-3 \mathrm{~cm}$ into each nostril and transported in a sealed container to the laboratory

149 without any transport media.

150

151 On arrival in the laboratory, all swabs were placed in $2 \mathrm{ml}$ Sarstedt containers with

$1521.5 \mathrm{ml}$ of sterile autoclaved $0.9 \%$ saline in preparation for downstream RT-PCR

153 testing. 
medRxiv preprint doi: https://doi.org/10.1101/2021.12.22.21268246; this version posted December 24,2021 . The copyright holder for this preprint (which was not certified by peer review) is the author/funder, who has granted medRxiv a license to display the preprint in

157 Swabs were tested by the Groote Schuur Hospital National Health Laboratory

158 Service (NHLS) diagnostic virology laboratory in Cape Town, South Africa. The

159 assays in used by this laboratory during the study period were the Allplex ${ }^{\mathrm{TM}}$ 2019-

160 nCoV assay (Seegene, South Korea) $(n=343)$, the Abbott RealTime SARS-CoV-2

161 assay (Abbott Laboratories, USA) $(n=7)$ and the Abbott Alinity m SARS-CoV-2 assay

162 (Abbott Laboratories, USA) $(n=32)$. The assay used was based on laboratory

163 operational requirements and no study-specific considerations or requirements were

164 in place. The Abbott assay were run as per kit package inserts and subject to the

165 operational requirements of a South African National Accreditation System (SANAS)

166 accredited diagnostic virology laboratory. The Seegene assay was run with an in-

167 house developed laboratory-specific sample processing technique which was subject

168 to a validation as per SANAS requirements. Paired samples were in all cases tested

169 using the same RT-PCR platform.

170

171 Selected samples $(n=31)$ that tested positive primarily were assessed for Spike gene

172 target failure using the TaqPath COVID-19 CE-IVD RT-PCR Kit (Thermo Fisher

173 Scientific, USA) at the Green Point NHLS diagnostic virology laboratory.

Variant classification

176

177 A confirmed classification as Delta or Omicron was based on whole genome sequencing as previously described. ${ }^{1}$ A probable assignment was based on variantspecific RT-PCR gene target failure profiles noted during diagnostic testing ${ }^{3,4}$ and a

180 possible assignment was based on the local dominant circulating variant at the time

181 of sample collection. ${ }^{1}$ RNA-dependent RNA-polymerase (RdRp) gene target failure 

medRxiv preprint doi: https://doi.org/10.1101/2021.12.22.21268246; this version posted December $24,2021$. The copyright holder for this
preprint (which was not certified by peer review) is the author/funder, who has granted medRxiv a license to display the preprint in It is made available under a CC-BY 4.0 International license.

182 (R-GTF) was considered present if the RdRp Ct value was $>3.5$ cycles greater than

183 the Envelope $(\mathrm{E})$ gene Ct value. In cases where the RdRp gene was not detected,

184 R-GTF was considered present if the $E$ gene had a Ct value of $<30$. Spike (S) gene

185 target failure was considered present if all assay SARS-CoV-2 gene targets other

186 than S were detected. The Delta variant was dominant in Cape Town prior to the $19^{\text {th }}$

187 of November 2021 and the Omicron variant subsequently (Supplementary Figure

188 1). ${ }^{1}$ For the purposes of positive percent agreement, negative percent agreement,

189 positive predictive value and negative predictive value calculation a Delta or Omicron

190 possible, probable or confirmed classification was accepted.

191

192 
medRxiv preprint doi: https://doi.org/10.1101/2021.12.22.21268246; this version posted December 24, 2021. The copyright holder for this preprint (which was not certified by peer review) is the author/funder, who has granted medRxiv a license to display the preprint in perpetuity.

It is made available under a CC-BY 4.0 International license .

A

\begin{tabular}{|c|c|c|c|c|c|c|c|c|}
\hline $\begin{array}{c}\text { Sample type and SARS-CoV-2 } \\
\text { lineage }\end{array}$ & $\begin{array}{c}\text { Positive } \\
\text { percent } \\
\text { agreement }\end{array}$ & $95 \% \mathrm{Cl}$ & $\begin{array}{c}\text { Negative } \\
\text { percent } \\
\text { agreement }\end{array}$ & $95 \% \mathrm{Cl}$ & $\begin{array}{c}\text { Positive } \\
\text { predictive } \\
\text { value }\end{array}$ & $95 \% \mathrm{Cl}$ & $\begin{array}{c}\text { Negative } \\
\text { predictive } \\
\text { value }\end{array}$ & $95 \% \mathrm{Cl}$ \\
\hline Midturbinate swab - Omicron & 86 & $71-94$ & 100 & $91-100$ & 100 & $89-100$ & 88 & $76-95$ \\
\hline Saliva swab - Omicron & 100 & $90-100$ & 100 & $91-100$ & 100 & $90-100$ & 100 & $91-100$ \\
\hline Midturbinate swab - Delta & 100 & $89-100$ & 100 & $99-100$ & 100 & $89-100$ & 100 & $99-100$ \\
\hline Saliva swab - Delta & 71 & $53-84$ & 100 & $99-100$ & 100 & $85-100$ & 97 & $94-98$ \\
\hline
\end{tabular}

B

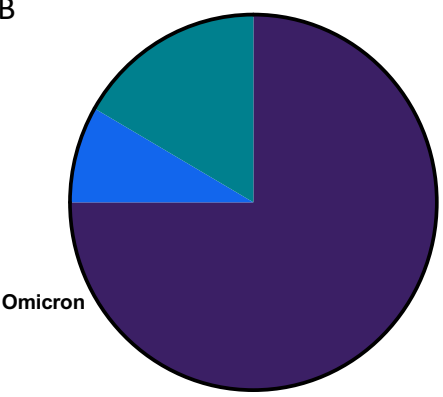

Total $=36$

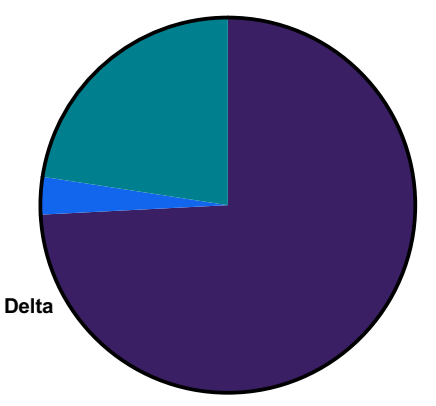

Total $=31$
Gene target failure of a diagnostic assay

$\square$ Whole genome sequencing

$\square$ Dominant variant at time of sample collection

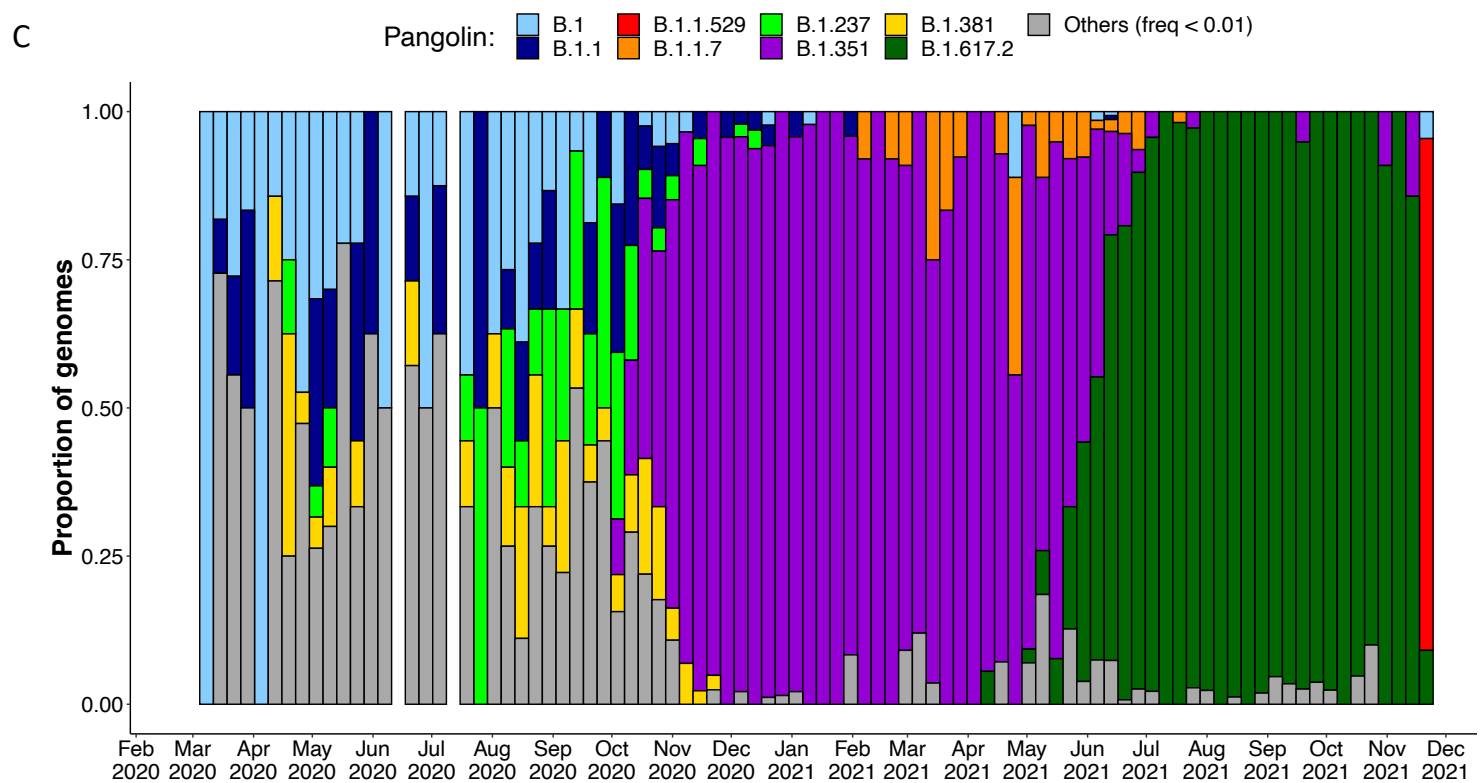

196 Supplementary Figure 1. (A) Table showing the positive and negative percent

197 agreement and positive and negative predictive values for mid-turbinate and saliva

198 swabs with 95\% confidence intervals shown. Confidence intervals were calculated

199 using the Wilson-Brown method using GraphPad Prism version 9.3.0 for macOS, 
medRxiv preprint doi: https://doi.org/10.1101/2021.12.22.21268246; this version posted December 24,2021 . The copyright holder for this preprint (which was not certified by peer review) is the author/funder, who has granted medRxiv a license to display the preprint in It is made available under a CC-BY 4.0 International license.

200 GraphPad Software, San Diego, California USA, www.graphpad.com. For the Delta

201 variant, 277 samples tested negative, for 22 samples both the saliva (SA) and mid-

202 turbinate (MT) swab tested positive and for 9 samples only the MT swab tested

203 positive. No samples tested SA swab positive only. For the Omicron variant, 38

204 samples tested negative, for 31 samples both the SA and MT swab tested positive

205 and for 5 samples only the SA swab tested positive. No samples tested MT swab

206 positive only. (B) The proportions of SARS-CoV-2 lineage assignments by listed

207 criteria for samples testing positive are shown. 36 samples were classified as

208 Omicron, 75\% as probable due to S gene target failure during diagnostic testing,

$20917 \%$ as possible due to the dominant circulating variant at the time of sample

210 collection and $8 \%$ as confirmed by whole genome sequencing. Similarly, 31 samples

211 were classified as Delta, $74 \%$ as probable due to RdRp gene target failure during

212 diagnostic testing, $23 \%$ as possible due to the dominant circulating variant at the

213 time of sample collection and $3 \%$ as confirmed by whole genome sequencing. (C)

214 The longitudinal proportion of Pangolin lineages for samples originating in the

215 Western Cape, South Africa. 